GRAÇA S. CARVALHO

\title{
5. HEALTH EDUCATION IN PORTUGUESE SCHOOLS
}

\author{
The Contribution of the Health and Education Sectors
}

\section{INTRODUCTION}

Children and young people spend a large part of their lives in school. In this environment they eat, drink, smoke, fall in love, speak about AIDS and about drugs, face stress, and experience a wide range of emotions. It is during this formative stage of their lives that our students most need to experience education in their schools that is directed toward preventing physical and mental health problems. In this chapter, I describe and discuss the Portuguese system of school health education and health promotion, which is strongly inspired by the European Network of Health Promoting Schools (ENHPS) and Schools for Health in Europe (SHE). I begin by outlining and comparing the two main perspectives informing the general health education framework. The first perspective focuses on the biomedical model of health and the second on the social (holistic) model of health. I also pay special attention to the roles that the Portuguese health and education sectors play in implementing school health education and health promotion.

\section{HEALTH VIEWS AND SCHOOL HEALTH EDUCATION} PERSPECTIVES - GENERAL BACKGROUND

From the Biomedical Model of Health to the Holistic View of Health

The traditional view of health as the absence of disease derives from a medical concept of disease as a pathological condition (a deviation from measurable variables that represent normal parameters in the healthy body) that can be diagnosed and categorized (Katz \& Peberdy, 1998). Evident within this model of health education is the assumption that the body works like a machine (Doyal \& Doyal, cited in Birk \& Silvertown, 1984). Thus:

- All parts of the body are connected but can be isolated and treated separately;

- Being healthy is to have all parts of the body in good working condition;

- Being ill is to have parts of the body working deficiently;

- Illness is caused by internal processes (age-related degeneration or deficient self-regulation) or external processes (invasion by pathogenic microorganisms);

- Medical treatment aims to restore the normal body functions, or health. 
In short, the biomedical model focuses explicitly on diseases and on their causes, treatment, and prevention. Health professionals, as the people equipped with the knowledge and skills to identify disease and its causes as well as to treat it, play a dominant role, often using persuasive and paternalistic methods during their work (Ewles \& Simnett, 1999). Under this model, it is health professionals who are responsible for ensuring that patients comply with medical prescriptions and for encouraging the use of procedures that (presumably) prevent and reduce disease.

Those who ascribe to the biomedical model see health education as a preventive procedure wherein people make behavioral changes that allow them to live healthier lives. The aim of school health education under the biomedical model, then, is to teach children and young people how to keep their bodies in good physical condition and how to avoid disease.

Health education within this framework appeared in Portuguese schools - and also in French and Spanish schools - at the end of the 19th century. Content was ordered into "lessons of morals" and "lessons of things" (Csergo, 2002) and focused on three main themes: hygiene, tuberculosis, and alcoholism. The health messages were informative and presented as injunctive, authoritative prescriptions, that is, rules to be obeyed (Sandrin-Berthon, 2000). The implicit idea was that once people received information about and understood what constituted unhealthy behavior, they would embrace healthy behaviors.

Interested in what keeps people healthy, Antonovsky (1987) developed a model opposite in nature to the dominant biomedical one. His model is based on what is known as the "salutogenic" (health-seeking) approach. In addition to focusing on the question of why some people remain healthy and others do not, this approach emphasizes "that stressors and disruption [are] ... unavoidable aspects of life rather than the demons they are portrayed to be in the pathogenic account" (Katz \& Peberdy, 1998, p. 31). The dynamic relationship between people and their environment is an essential element of this model, and emphasis is given to the personal resources that people need to cope with the challenges they face. In order to deal effectively with stressors, people need to create "a sense of coherence" for themselves by integrating three components: comprehensibility, manageability, and meaningfulness. According to Antonovsky (1987, p. 19), coherency is achieved when

1. The stimuli deriving from one's internal and external environments in the course of living are structured, predictable, and explicable;

2. The resources are available to meet the demands posed by the stimuli; and

3. These demands are challenges worthy of investment and engagement.

The salutogenic paradigm provides an interesting bridge between the biomedical model and the social model of health. The social model of health, in line with the salutogenic paradigm, assumes a holistic perspective and emphasizes the interaction between persons and the environment. It adopts the logic of multicausal theories of health, and it assumes that health is influenced not only by biological factors but also by political, economic, social, psychological, cultural, 
and environmental factors (Carvalho, 2006; Ewles \& Simnett, 1999; Katz \& Peberdy, 1998; Naidoo \& Wills, 1994).

The social model of health does not dispense with medicine; rather, it positions the medical model as just one part of the answer. Those adhering to the social model recognize that improving people's health requires early identification of the causes of ill-health in persons and communities, such as housing and nutrition and societal and personal hygiene factors (Katz \& Peberdy, 1998).

The aim of health education within the social model of health is to develop positive attitudes toward and behaviors associated with good health and wellbeing. While this approach may lead to people taking on a healthier lifestyle in order to improve some facet of their health, the focus is not on disease prevention, as it is in the biomedical model of health education. Health education predicated on a social health model endeavors to provide people with knowledge and understandings that enable them not only to make well-informed decisions but also to explore their values and attitudes (Carvalho et al., 2008).

School-based health education likewise emphasizes skills development and behavior change rather than acquisition of facts. It thus takes a much broader view than traditional biomedical-based health education, which focuses only on formal classroom activities. Holistic school health education also addresses the development of healthy lifestyles and healthy environments, including the social and physical environments in schools. Thus, the aim of social (holistic) school health education is to help children and young people develop healthy living competencies within an environment that is conducive to their physical, mental, and social wellbeing (Carvalho, 2002; Carvalho \& Carvalho, 2006; Ewles \& Simnett, 1999).

\section{School Health Promotion: From ENHPS to SHE}

The health promoting schools notion is based on the World Health Organization's (WHO) view that health education and health promotion must take account of the particular nature of the communities and societies that the educational initiative is targeting. Although there are many models of health promoting schools, they are all based on the five strategies of the Ottawa Charter (WHO, 1986), albeit adapted to the school setting (WHO, cited in Colquhoun, 1997):

- Ensuring practice is based on health promoting policy-by drawing together biological, ecological, social, and environmental dimensions to ensure the development of coherent health-based education curricula;

- Creating supportive environments - by utilizing the setting of the school to encourage reciprocal support among teachers, students, and parents;

- Strengthening community action - by drawing on existing human and material resources in the community in which the school is set and involving that community in practical aspects of health education, decisionmaking, and planning; 
- Developing personal skills - by providing students not only with information on and understanding about health but also opportunities to enhance life skills in the setting of the school community; and

- Reorienting health services - by involving school health services in project activities aimed at promoting health and by utilizing the skills of school health professionals on a basis broader than the traditional.

These precepts of the health promoting schools concept have inspired health education in Portuguese schools. Portugal is a member of the European Network of Health Promoting Schools (ENHPS), which was launched in 1991 as a joint and collaborative effort between the WHO Regional Office for Europe, the Commission of European Communities, and the Council of Europe.

According to the WHO Regional Office for Europe (cited in Parsons, Steers, \& Thomas, 1996, p. 311), "The health promoting school aims at achieving healthy lifestyles for the total school population by developing supportive environments conducive to the promotion of health. It offers opportunities for, and requires commitments to, the provision of a safe and health-enhancing environment."

The overall aim of the ENHPS not surprisingly aligns with this aim. Its goal is to "influence and have impact on policy and decision making in the development, implementation and sustainability of health promoting schools in European countries. This aim is achieved through capacity building, resource development, research and evaluation, advocacy and dissemination" (ENHPS, 1997, p. 1).

Despite the diversity in culture and educational settings throughout Europe, there is general agreement across these settings on the aims of health promoting schools. According to Barnekow et al. (2006, p. 13), there are 10 such aims:

1. To establish a broad view of health;

2. To give students tools to enable them to make healthy choices;

3. To provide a healthier environment by engaging students, teachers, and parents, using interactive learning methods, building better communication channels, and seeking partners and allies in the community;

4. To have all members of the school community (students, their parents, teachers, and all other people working in the environment) clearly understand the "real value of health" (physical, psychosocial, and environmental) - both present and future - and how to promote it for the wellbeing of all;

5. To be an effective (perhaps the most effective) long-term workshop for practicing and learning humanity and democracy;

6. To increase students' agency with respect to health, that is, empowering them to take action, individually and collectively, for a healthier life and for healthier living conditions locally as well as globally;

7. To make healthier choices easier choices for all members of the school community;

8. To promote the health and wellbeing of students and school staff; 
9. To enable people to deal with themselves and the external environment in a positive way and to facilitate healthy behavior through development and implementation of policies; and

10. To increase the quality of life.

In 2008, the International Union for Health Promotion and Education (IUHPE) clarified the concepts of health education and health promotion as they relate to schools. Health education is "a communication activity ... [which] involves learning and teaching pertaining to knowledge, beliefs, attitudes, values, skills and competencies" (IUHPE, 2008, p. 3). Health promotion is "any activity undertaken to protect or improve the health of all school users" (IUHPE, 2008, p. 3). Although both concepts emphasize the participative approach to learning, the latter is a broader concept that goes beyond classroom activities and curriculum implementation.

The Schools for Health in Europe (SHE) network is the continuation of ENHPS. It began in January 2007. The network is currently present in 46 European countries, including Portugal (DGIDC, 2010a). Its aim is to support organizations and professionals in Europe who work in the field of school health promotion, by sharing with them good practice, expertise, and skills (SHE, 2008). All health promoting schools involved in the SHE network are expected to value and develop the following:

- Equity - equal access for all to the full range of educational opportunities;

- Participation - a sense of ownership brought about by students' participation;

- Empowerment-students developing their own ideas about healthy lifestyles and making active and healthy choices;

- A healthy environment - includes the physical environment, and the quality of the relationships among and between students and staff and with parents and the community;

- Effective policies-developed locally and reflecting local interests, problems, and priorities (SHE, 2008).

There is growing evidence that the health promoting schools approach has a positive impact on teaching and learning within the school. Advantages include higher academic achievement, a lesser likelihood of students leaving school early, and higher job satisfaction for staff (Barnekow et al., 2006; Leger, Kolbe, Lee, McCall, \& Young, 2007; Mérini, Jourdan, Victor, Berger, \& De Peretti, 2000; SHE, 2008).

\section{HEALTH EDUCATION IN PORTUGUESE SCHOOLS}

Different countries address educational policies in different ways for reasons relating to political orientation and to the goals, priorities, and organization of their respective education systems (Pommier \& Jourdan, 2007). In some countries, regional or local authorities are responsible for developing education (including health) policies. In other countries, Portugal being one, policy (again including health) is formulated at the national level. In Portugal, the Ministry of Education translates national government policy into curricula and their associated guidelines 
and standards (DGIDC, 2010b). However, the health sector also works in partnership with the ministry to develop and implement health education.

\section{Education Sector and Health Sector Tensions}

In Portugal, the education sector's holistic view of the health education curriculum fits well with the health promotion approach set down by the health sector. However, tensions can arise because the limited time usually available for addressing the various areas of the formal national curriculum means that health issues can be pushed to one side. Despite this difficulty, it is encouraging to find that the broader view of health evident within the informal school curriculum supports the health promotion approach advocated by the health sector (Barnekow et al., 2006).

The particular words and terms that education specialists and health specialists use can be a source of difficulty and tension when the two sectors work in partnership (Kemm, 2006). For example, for the education sector, the term "curriculum" usually means the totality of learning experiences the school offers to children and young people (i.e., the formal and informal curriculum referred to previously). In contrast, the term curriculum for the health sector typically refers to syllabus guidelines or to classroom teaching and learning activities; the wider influence of the school is encompassed within "the whole-school effect" or the notion of health promoting schools.

Also, the education sector naturally gives priority to education, whereas the health sector gives priority to health. Each therefore has different starting points, generating different priorities and possibly different perspectives about which model of health promotion schools should adopt.

The spirit of partnership between the two sectors requires their respective professionals to be aware of these difficulties and to work with an open and positive attitude toward achieving their slightly different aims. These tensions between the sectors may be lessening, however, given evidence that health promotion initiatives are having a positive impact on students' learning outcomes (Barnekow et al., 2006; Leger et al., 2007; Mérini et al., 2000; SHE, 2008).

\section{Health Sector Participation in School Health Education and Promotion}

In Portugal, local health services meet their responsibility for providing children and young people with health care by providing their services directly to students or schools. The section on school health within the Portuguese National Health Plan 2004-2010 (Ministry of Health, 2010) requires health services and schools to work together to provide students with health-promotion and disease-prevention strategies throughout the academic year, and beyond. These activities include monitoring children's health (including vaccination uptake) according to standards set down in the National Health Plan; making sure that children's health needs are met quickly and efficiently (this includes ready access to medical facilities); promoting oral health; and encouraging healthy lifestyles. 
Local health centers also collaborate closely with schools to deliver particular facets of the health education curriculum and to promote amelioration of several issues. Content focuses on healthy food (under the slogan, healthy eating means a healthy lifestyle); prevention of bullying; sex and emotions; HIV/AIDS; and prevention of substance abuse and dependency (alcohol, tobacco, and other drugs). The health centers furthermore work in partnership with local communities (i.e., municipalities) to improve health and safety conditions within schools (e.g., buildings) and their surroundings (Ministry of Health, 2010).

Table 1 outlines the school goals that the Ministry of Health set down for 2010 (Ministry of Health, 2010, p. 1). Over-arching goals were for all health centers in Portugal to have school health teams, all schools to experience hygiene and safety evaluations, and all health-promotion interventions to be supported by well-defined implementation guidelines.

Health education in Portugal is an important component of school activity, but it must take into account the setting in which it is conducted. The school is, first of all, a place of cognitive and social learning, and so not really a place of healing. Schools should therefore not focus on health risks and diseases. Ideally, they should be ever mindful that good health enhances learning outcomes (IUHPE, 2008) and offers experiences and teaches skills that enable children and young people to be agentic in improving their own health and wellbeing and that of others in their community. Tones and Tilford (1994, p. 11) capture this thinking:

Health education is any intentional activity which is designed to achieve health or illness related learning, i.e. some relatively permanent change in an individual's capability or disposition. Effective health education may, thus, produce changes in knowledge and understanding or ways of thinking; it may influence or clarify values; it may bring about some shift in belief or attitude; it may even effect changes in behavior or lifestyle.

\section{Education Sector Participation in School Health Education and Promotion}

Changing to healthier behaviors is a relatively complex process that depends, among other factors, on each individual's personal attitudes toward general health, health risks, and health topics (nutrition, sexuality, etc.). Attitudes are, in this context, judgments that are more or less favorable with respect to health issues. These judgments depend on individuals' knowledge (health subject matters), beliefs, and social representations, as well as the generated emotional reactions and intended reactions (Larue, Fortin, \& Michard, 2000). The Portuguese Ministry of Education (DGIDC, 2010b, p. 1) thus states that in "the school context, health education consists of providing children and young people with knowledge, attitudes and values that can help them select options and make decisions appropriate to their health and to their physical, social and mental wellbeing."

The Portuguese Ministry of Education, which is responsible for monitoring and assessing school health activities, pays particular heed to five priority topics, all of which align with health sector priorities (see above). These are healthy food and physical activity, prevention of alcohol and drug abuse, sex education, sexually 
transmitted infections, and mental health and prevention of school bullying (DGIDC, 2010c).

Table 1. School health goals for 2010

\begin{tabular}{|c|c|c|}
\hline Indicator & $\begin{array}{c}\text { Situation in } 2009 \\
\text { (percentages meeting } \\
\text { goals) }\end{array}$ & $\begin{array}{c}\text { Goals for } \\
2010 \\
\text { (target } \\
\text { percentages) }\end{array}$ \\
\hline $\begin{array}{l}\text { - Health centers with school health teams } \\
\text { - Health status of six-year-old students } \\
\text { monitored } \\
\text { - Health status of 13-year-old students } \\
\text { monitored } \\
\text { - Preschool students up to date with } \\
\text { vaccinations } \\
\text { - Six-year-old students up to date with } \\
\text { vaccinations } \\
\text { - Thirteen-year-old students up to date with } \\
\text { vaccinations } \\
\text { - Students with particular health needs have } \\
\text { those needs addressed by the end of the } \\
\text { school year } \\
\text { - Hygiene and safety in all schools evaluated } \\
\text { - Schools meet "good" standards of hygiene } \\
\text { and safety } \\
\text { - School buildings and surroundings show } \\
\text { "good" standards of hygiene and safety } \\
\text { - Health-promotion interventions supported by } \\
\text { well-defined implementation guidelines } \\
\text { - Six-year-old students free of caries (tooth } \\
\text { decay) } \\
\text { - CLFD index (number of adult teeth with } \\
\text { caries, lost, or filled) conducted of all } 12 \text {-year- } \\
\text { old children } \\
\text { - Twelve-year-old children needing dental } \\
\text { treatment, treated by end of school year }\end{array}$ & $\begin{array}{l}96 \\
71 \\
31 \\
82 \\
90 \\
78\end{array}$ & $\begin{array}{c}75 \\
100 \\
90 \\
60 \\
100 \\
65\end{array}$ \\
\hline
\end{tabular}

In Portugal, as in other countries, school health education tends to be based on a topic approach, which means each of the topics just mentioned is taught separately. Various stakeholders have criticized this approach. It can be "problematic or ineffective as such approaches are sometimes based on assumptions relating to human behaviour, which are difficult to justify and not supported by evidence" (IUHPE, 2008, p. 4). Because teaching the topics separately (and properly) represents a very large portion of teaching time-time that teachers usually do not have-teachers tend to respond by transmitting information only (Pizon, 2008). Therefore, instead of teachers taking on an exhaustive approach, topic by topic, a more effective approach is for them to 
develop children's and young people's life skills and competencies, so enabling them to consider different health topics within the reality of the social and environmental contexts of their lives (IUHPE, 2008).

\section{CONCLUSION}

When health education centers neither on disease nor on risk behaviors but on empowering people, mere transmission of knowledge in classrooms about different health-related risk behaviors is not enough. Sustainable and effective prevention of health risks supports people in ways that enable them to take responsibility for their own health and for the health of others in their families and communities (Pizon, 2008).

The health promoting schools concept places considerable emphasis on empowering students and building their capacity to make healthy choices (Leger et al., 2007). Children and young people can thus have an important role in healthy school initiatives, such as the food provided in the school canteen, a clean safe physical environment, and policies concerning social matters, such as bullying. When children and young people collectively work toward securing good healthphysical, environmental, and social - they cannot help but work toward a healthier society, both within and beyond the school gates.

\section{REFERENCES}

Antonovsky, A. (1987). Unravelling the mystery of health: How people manage others and stay well. New York: Wiley.

Barnekow, V., Buijs, G., Clift, S., Jensen, B. B., Paulus, P., Rivett, D., \& Young, I. (2006). Healthpromoting schools: A resource for developing indicators. Copenhagen, Denmark: Council of Europe, World Health Organization, European Commission.

Birk, L., \& Silvertown, J. W. (1984). More than the parts: Biology and politics. London, UK: Pluto Press.

Carvalho, A., \& Carvalho, G. S. (2006). Educação para a Saúde: Conceitos, práticas e necessidades de formação [Health education: Concepts, practices and training needs]. Loures, Portugal: Lusociência.

Carvalho, G. S. (2002). Literacia para a Saúde: Um contributo para a redução das desigualdades em saúde [Health literacy: A contribution to reducing inequalities in health]. In M. E. Leandro, M. M. L. Araújo, \& M. S. Costa (Eds.), Saúde: As teias da discriminação social-Actas do Colóquio Internacional: Saúde e Discriminação Social [Health: The webs of social discrimination. Proceedings of the International Conference on Health and Discrimination] (pp. 119-135). Braga, Portugal: University of Minho.

Carvalho, G. S. (2006). Criação de ambientes favoráveis para a promoção de estilos de vida saudáveis [Creating environments that promote healthy lifestyles]. In B. Pereira \& G. S. Carvalho (Eds.), Actividade Física, Saúde e Lazer: A Infância e Estilos de Vida Saudáveis [Physical activity, health and leisure: Children and healthy lifestyles] (pp. 19-37). Lisbon, Portugal: Lidel.

Carvalho, G. S., Dantas, C., Rauma, A.-L., Luzi, D., Ruggier, R., Geier, C., Caussidier, C., Berger, D., \& Clément, P. (2008). Comparing health education approaches in the textbooks of sixteen countries. Science Education International, 19(2) 133-146.

Colquhoun, D. (1997). The health promoting school in Australia: A review. International Journal of Health Education, 35, 117-125.

Csergo, J. (2002). Propreté et enfance au XIX siècle [Hygiene and childhood in the 19th century]. In D. Nourisson (Ed.), Éducation à la Santé: XIX $-X X^{e}$ siècle [Health education from the 19th to the 20th centuries] (pp. 43-56). Rennes, France: Editions ENSP. 


\section{CARVALHO}

Directorate General for Innovation and Curriculum Development (DGIDC). (2010a). SHE. Retrieved from http://www.dgidc.min-edu.pt/SAUDE/Paginas/she.aspx.

Directorate General for Innovation and Curriculum Development (DGIDC). (2010b). Educação para a Saúde [Health education]. Retrieved from http://www.dgidc.min-edu.pt/saude/Paginas/default.aspx.

Directorate General for Innovation and Curriculum Development (DGIDC). (2010c). Educação para a Saúde: Áreas Prioritárias [Health education: Priority areas]. Retrieved from http://www.dgidc.minedu.pt/SAUDE/Paginas/areas_Prioritarias.aspx.

European Network of Health Promoting Schools (ENHPS). (1997). [Website]. Retrieved from http://ec.europa.eu/health/ph_overview/previous_programme/promotion/networks_enhps_ promotion en.htm.

Ewles, L., \& Simnett, I. (1999). Promoting health: A practical guide. London, UK: Baillière Tindall.

International Union for Health Promotion and Education (IUHPE). (2008). Achieving health promoting schools: Guidelines for promoting health in schools. Saint-Denis, France: Author.

Katz, J., \& Peberdy, A. (1998). Promoting health: Knowledge and practice. London, UK: MacMillan.

Kemm, L. (2006). The limitations of evidenced public health. Journal of Evaluation in Clinical Practice, 12, 319.

Larue, R., Fortin J., \& Michard J.-L. (2000). Ecole et santé: Le pari de l'éducation, collection enjeux du système éducatif [School and health: The challenge of education, critical issues in the education system.]. Paris, France: Hachette Education.

Leger, L. St., Kolbe, L., Lee, A., McCall, D. S., \& Young, I. M. (2007). School health promotion: Achievements, challenges and priorities. In D. V. McQueen \& C. M. Jones (Eds.), Global perspectives on health promotion effectiveness (pp. 107-124). New York: Springer.

Mérini C., Jourdan, D., Victor, P., Berger, D., \& De Peretti, C. (2000). Guide ressource pour une éducation à la santé à l'école primaire [Guidelines for health education in primary schools]. Rennes, France: Editions ENSP.

Ministry of Health. (2010). Plano Nacional de Saúde 2004-2010 [National Health Plan 2004-2010]. Retrieved from http://www.dgsaude.min-aude.pt/pns/vol1_531.html.

Naidoo, J., \& Wills, J. (1994). Health promotion: Foundations for practice. London, UK: Baillière Tindall.

Parsons, C., Stears, D., \& Thomas, C. (1996). The health promoting school in Europe: Conceptualising and evaluating the change. Health Education Journal, 55, 311-321.

Pizon, F. (2008). Education et santé au lycée: Quelle contribution à la prévention du tabagisme pour les professionnels? [Education and health in high schools: What influence does it have on preventing smoking amongst professionals?]. Unpublished doctoral dissertation, Blaise Pascal University, Clermont-Ferrand, France.

Pommier, J., \& Jourdan, D. (2007). La santé à l'école dans les pays Européens [School health education in European countries]. Paris, France: Sudel.

Sandrin-Berthon, B. (2000). Approche historique de l'éducation pour la santé à l'école [Historical approaches to health education in schools]. La Santé de l'Homme, 346.

Schools for Health in Europe (SHE). (2008). Who is SHE? SHE Newsletter, September.

Tones, K., \& Tilford, S. (1994). Health Education: Effectiveness, efficiency and equity. London, UK: Chapman \& Hall.

World Health Organization (WHO). (1986). Ottawa Charter for Health Promotion: First International Conference on Health Promotion, Ottawa, Canada. Retrieved from http://www.who.int/hpr/NPH/ docs/ottawa_charter_hp.pdf.

Graça S. Carvalho

University of Minho

Braga

Portugal

email: graca@ie.uminho.pt 
Health Education in Context: An International Perspective on Health Education in Schools and Local Communities

\section{Editors}

Neil Taylor, Frances Quinn and Michael Littledyke

University of New England, Armidale, Australia

and

Richard K. Coll

University of Waikato, Hamilton, New Zealand

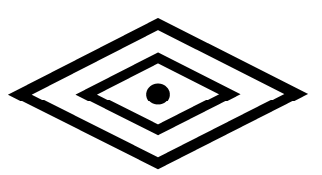

SENSE PUBLISHERS

ROTTERDAM/BOSTON/TAIPEI 
A C.I.P. record for this book is available from the Library of Congress.

ISBN: 978-94-6091-874-2 (paperback)

ISBN: 978-94-6091-875-9 (hardback)

ISBN: 978-94-6091-876-6 (e-book)

Published by: Sense Publishers,

P.O. Box 21858

3001 AW Rotterdam,

The Netherlands

http://www.sensepublishers.com

Printed on acid-free paper

All Rights Reserved (C) 2012 Sense Publishers

No part of this work may be reproduced, stored in a retrieval system, or transmitted in any form or by any means, electronic, mechanical, photocopying, microfilming, recording or otherwise, without written permission from the Publisher, with the exception of any material supplied specifically for the purpose of being entered and executed on a computer system, for exclusive use by the purchaser of the work. 


\section{TABLE OF CONTENTS}

\section{Preface and Overview}

1 Health education in context: An overview, and some observations Neil Taylor, Frances Quinn, Michael Littledyke \& Richard K. Coll

Pacific

2 Whole school approaches to health promotion: The Pacific journey Sereana Tagivakatini \& Temo K. Waqanivalu

\section{Middle East and Gulf}

3 Health education in the Sultanate of Oman: Towards sustainable health for students Abdullah Ambusaidi \& Sulaiman Al-Balushi

4 Health education through extra curricular activities in Lebanon: Process and challenges

Mayada Kanj

\section{Europe}

5 Health education in Portuguese schools: The contribution of the health and education sectors Graça S. Carvalho

6 The possibility of health education in an education-based society: The case of Hungary Magdolna Chrappán

7 An overview of formal and non-formal health education in Turkey Muammer Çalık \& Gamze Çan

8 Education for healthy lifestyles in the European north of Russia: Developments and dilemmas Marina Gvozdeva \& Valentina Kirilina

9 The role of health education in preventing diseases: A case study from Poland

Joost Platje \& Krystyna Stodczyk

Africa

10 Lifting the lid on HIV/AIDS and tuberculosis in Malawi Gilbert R. Phiri 
TABLE OF CONTENTS

11 Medical research in South Africa: Education and ethics Francesca Conradie

12 The development of the school health policy and curriculum in Nigeria Olawale A. Moronkola

13 The child-to-child curriculum in East Africa (Kenya and Tanzania): Strengths, challenges, and weaknesses

Henry Sammy Wanyama \& Kalafunja Mlang'a O-saki

14 Health education in Ethiopia: Practices, challenges, and prospects Frehiwot Wubshet \& Temechegn Engida

15 The status of health education in Namibian schools Choshi D. Kasanda, Maria Charlotte Keyter, \& Donovan Zealand

16 Environmental problems and their impact on people's health: The Nigerian context

Josiah O. Ajiboye \& Folashade Afolabi

\section{South Asia}

17 Promoting healthy ageing:

Experience from tea estate communities in Sri Lanka

Wendy R. Holmes \& Jennifer Joseph

18 Educating Indian children about the impact of climate change on health Shyamala Mani, D. K. Banerjee, Divya Pant, Priyanka Porwal, \& Shefali Godura

19 Health education in primary schools in Pakistan: Perils and promises Sadia Muzaffar Bhutta

20 Health and sex education in India: The collapse of a policy Mala Sharda \& Mike Watts

\section{East Asia}

21 Malaysian traditional knowledge and herbal gardens: Informal education on plant resources for health

Noor Azlin Yahya \& Nor Azah Mohd. Ali

22 Supporting health education in Thai contexts:

Conceptualizing and evaluating the change

Tussatrin Kruatong \& Chanyah Dahsah 
23 Priorities for health education in Hong Kong in relation to non-communicable diseases

Emmy Man Yee Wong \& May May Hung Cheng

24 Working towards a healthier Brunei

Irene Poh-Ai Cheong

25 Integration of Health Education for Sustainable Development: Sabah's Initiatives

Mohd. Zaki Ishak \& Hamzah Md. Omar

26 Mental health education and training in Vietnam: The role of clinical psychology

Hoang-Minh Dang \& Bahr Weiss

27 Health education in China (1978-2010): Challenges and reforms Yimin Wang

\section{Conclusions and Implications}

28 The influence of context on health education:

Observations, conclusions, and some recommendations

Neil Taylor, Frances Quinn, Michael Littledyke \& Richard K. Coll 